\title{
To study the effect of pterygium excision on corneal curvature and contrast sensitivity
}

\author{
Kujur $\mathbf{R}^{1}$, Vohra $\mathbf{M}^{2}$, Adlakha $\mathbf{N}^{3}$, Shakya D.K ${ }^{4}$, Shukla $\mathrm{A}^{5}$ \\ ${ }^{1}$ Dr. Rashmi Kujur, Assistant Professor, ${ }^{2}$ Dr. Malini Vohra, Junior resident, ${ }^{3}$ Dr. Neha Adlakha, Junior resident, ${ }^{4}$ Dr. D. \\ K. Shakya, Professor, ${ }^{5}$ Dr Abha Shukla, Assistant Professor. All are affiliated with, Department Of Ophthalmology, \\ G.R.M.C, Gwalior, Madhya Pradesh- 474009, India
}

Address for correspondence: Dr. Rashmi Kujur, Email: drrashtirkey@gmail.com

\begin{abstract}
Introduction: To evaluate the corneal astigmatism and contrast sensitivity before and after pterygium surgery and to study the relationship between amount of astigmatism and contrast sensitivity in various grades of pterygia. Material and Method: Sixty three eyes of 63 patients with primary pterygia were studied before and after surgery. The astigmatism induced by primary pterygium was measured by manual keratometer and contrast sensitivity by Pelli Robson chart. Preoperative and postoperative values were compared using paired t -test and ANOVA test. Result: Astigmatism decreased significantly following pterygium excision. The mean preoperative refractive cylinder decreased from $3.29 \pm 1.46 \mathrm{D}$ to $1.49 \pm 0.82 \mathrm{D}$ postoperatively. Surgical removal of pterygium caused a significant reduction in refractive astigmatism. The amount of astigmatism decreased significantly following pterygium excision in grade II , grade III and in grade IV. In grade I pterygium, decrease in the amount of astigmatism was not statistically significant $(\mathrm{p}=0.515)$. The contrast sensitivity increased significantly following pterygium excision. The mean preoperative contrast sensitivity increased from $1.49 \pm 0.21$ to $1.70 \pm 0.20$ postoperatively. Surgical removal of pterygium caused a significant improvement in contrast sensitivity. Conclusions: Surgical excision of pterygium improves contrast sensitivity, visual acuity and reduces astigmatism. Contrast sensitivity testing may provide additional objective methods for documenting impaired vision in patients with pterygium when Snellen visual acuity is minimally affected Corneal astigmatism and contrast sensitivity values in patients with pterygia are useful indicators for the need of pterygium surgery or as indicators of surgical success.
\end{abstract}

Key words: Pterygium, Astigmatism, Contrast Sensitivity, Corneal Curvature, Pelli Robson Chart.

\section{Introduction}

Pterygium is a triangular, wing like fibrovascular encroachment of degenerative sub-epithelial conjunctiva, straddling the limbus, onto the cornea. It is associated with ultraviolet-light exposure (e.g., sunlight), low humidity, and dust. Ninety percent of pterygia are located nasally. Nasal and temporal pterygia can occur in the same eye, but isolated temporal pterygia are extremely rare. Both eyes are frequently involved, but often asymmetrically. It is unusual for the apex to extend across the midline. In rare instances, extensive pterygia can advance from the medial and lateral limbus to encroach visual axis, causing marked loss of acuity. Pterygium is a common disorder in many parts of the world, with reported

Manuscript received: $15^{\text {th }}$ Oct 2015

Reviewed: $28^{\text {th }}$ Oct 2015

Author Corrected: $13^{\text {th }}$ Nov 2015

Accepted for Publication: $23^{\text {rd }}$ Nov 2015 prevalence rates ranging from 0.3 to $29 \%$. Pterygium is commonly seen in India, a part of the "pterygium belt" described by Cameron [1]. A "pterygium belt" has been mapped within the 30th parallels and is rare in north or south of the 40th parallels. Studies suggest an association with chronic exposure to UV- B radiations $[2,3]$. Localized limbal stem cell anomalies, human papilloma virus infection, p53 gene mutations and imbalance of matrix metalloproteinases (MMP) and tissue inhibitors of metalloproteinases (TIMP) have been strongly implicated in pterygium causation. These recent insights into the aetio-pathogenesis of pterygium help us in deciding the management strategies.

Most patients of pterygium take treatment for cosmetic purpose. Pterygium leads to inflammation, foreign body sensation, lacrimation, dry and itchy eye. The indications for pterygium surgery are cosmetic 
disfigurement, visual impairment, recurrent inflammation and motility restriction.

Contrast sensitivity is closely correlated with the ability to detect and discriminate between visual targets. It refers to the ability to distinguish an object from other objects and the background, even when it is not clearly outlined or prominent. Contrast sensitivity is a very important measure of visual function, especially in situations of low light, fog or glare, when the contrast between objects and their background often is reduced. Some tasks requiring distance judgement, night driving and mobility are more closely related to contrast sensitivity than to visual acuity.

Contrast sensitivity loss can occur secondary to optical or neural loss, due to corneal scarring, optic nerve damage, or cataract. It is crucial for daily living skills and therefore would have an impact on functional employment skills. It is the best predictor of visual function, even more so than visual acuity which only measures high contrast letters.

Pterygium causes reduction in contrast sensitivity. Both spatial contrast sensitivity and glare disability are worsened in patients with pterygia even when the Snellen's visual acuity is minimally affected. Thus, the present study was determine the effect of pterygium excision on induced astigmatism and contrast sensitivity.

\section{Materials and Methods}

A prospective study was conducted in the Department of Ophthalmology, Gajra Raja Medical College, Gwalior for the period of September 2013 to October 2014. Sixty three eyes of 63 patients with primary pterygia were studied before and after surgery.

Inclusion criteria- Patients with primary pterygium with $\geq 2$ D astigmatism were included in study.

Exclusion criteria: - Pterygium with any anterior or posterior segment pathology was excluded from study.

The astigmatism induced by primary pterygium was measured by manual keratometer and Contrast sensitivity was measured by Pelli Robson contrast sensitivity chart.

Nasal pterygium was graded depending on the extent of corneal involvement.

GradeI - Pterygium crossing limbus $<2 \mathrm{~mm}$ onto cornea.
Grade II - Pterygium crossing limbus onto $\geq 2-4 \mathrm{~mm}$ of cornea.

Grade III - Pterygium crossing limbus onto $>4 \mathrm{~mm}$ of cornea and reaching up to pupillary margin

Grade IV- Pterygium crossing pupillary margin.

All surgeries were performed under peribulbar anaesthesia .A small conjuctival incision was made medial to head of pterygium and subconjuctival dissection carried out up to caruncle superior and inferior fornix . The corneal epithelium $2 \mathrm{~mm}$ anterior of head was scrapped off with blade no. 11 Bard Parker blade and the pterygium head avulsed using a combination of blunt dissection and traction. The body of pterygium was then excised. Haemostasis was achieved by applying light cautery to bleeders. After the pterygium mass was removed, a limbal-conjunctival autograft was procured from the superior conjunctiva; the graft dissection was extended approximately 0.5 $\mathrm{mm}$ into clear cornea to include the Vogt palisades and limbal stem cells. This graft was moved to cover the defective area and was secured with 10-0 nylon sutures. The limbal end of the autograft was placed directly over the limbal area of the surgical bed. The sutures were removed under the operating microscope after conjunctival epithelialization occurred. Examination included -Snellen visual acuity, slit lamp examination, manual keratometry, contrast sensitivity with pelli robson chart was done pre-operatively and one month postoperatively.

Contrast Sensitivity Examination- Contrast sensitivity was recorded using Pelli-Robson chart. Subject was seated in front of Pelli-Robson chart at a distance of 1 meter with the best distance correction [2]. Subject is asked to outline each letter on the chart. Test is concluded when the subject guesses two of the three letters of the triplet incorrectly. Subject's sensitivity is indicated by the finest triplet for which two of the three letters are named correctly.

Preoperative and postoperative values were compared using paired $\mathrm{t}$-test.

Preoperative astigmatism and contrast sensitivity was compared against the grade of pterygium using ANOVA test [4].

Statistical analysis: Analysis Of Variance : Analysis of variance (ANOVA) is a collection of statistical models and their associated procedures, in which the 
observed variance in a particular variable is partitioned into components attributable to different sources of variation. In its simplest form, ANOVA provides a statistical test of whether or not the means of several groups are all equal, and therefore generalizes t-test to more than two groups. Doing multiple two sample ttests would result in an increased chance of committing a type I error. For this reason, ANOVAs are useful in comparing two, three, or more means. A test result (calculated from the null hypothesis and the sample) is called statistically significant if it is unlikely to have occurred by chance alone. A statistically significant result when a probability ( $\mathrm{p}$-value) is less than a threshold (significance level)) justifies the rejection of the null hypothesis. Rejecting the null hypothesis implies that different treatments result in altered effects.

\section{Observations and Results}

Table Nos. 1: Distribution of cases according to age and sex

\begin{tabular}{|l|l|l|l|}
\hline & Female & Male & \\
\hline Age in years & $\begin{array}{l}\text { No. of } \\
\text { Patients }(\%)\end{array}$ & $\begin{array}{l}\text { No. of } \\
\text { Patients. }(\%)\end{array}$ & $\begin{array}{l}\text { Total No. of Patients } \\
(\%)\end{array}$ \\
\hline$<20$ & & $1(1.58 \%)$ & $1(1.58 \%)$ \\
\hline$>20-40$ & $10(15.87 \%)$ & $3(4.76 \%)$ & $13(20.63 \%)$ \\
\hline $40-60$ & $11(17.46 \%)$ & $27(42.85 \%)$ & $38(60.31 \%)$ \\
\hline$>60$ & $5(7.94 \%)$ & $6(9.52 \%)$ & $11(17.46 \%)$ \\
\hline TOTAL & $\mathbf{2 6 ( 4 1 . 2 7 \% )}$ & $\mathbf{3 7 ( 5 8 . 7 3 \% )}$ & $\mathbf{6 3 ( 1 0 0 \% )}$ \\
\hline
\end{tabular}

Table 1 shows the age and sex distribution of cases ranged between 19 and 80 years (mean age $51.55 \pm 13.18$ year).Maximum number of cases belonged to $20-60$ years of age $(80.94 \%)$. Prevalence was more in males $(58.73 \%)$ as compared to females $(41.27 \%)$.

Table No. 2: Grade wise distribution of cases/eyes

\begin{tabular}{|l|l|l|}
\hline Grades of Pterygium & No. of Patients & \% of Patients \\
\hline Grade I & 8 & 12.69 \\
\hline Grade II & 27 & 42.85 \\
\hline Grade III & 25 & 39.68 \\
\hline Grade IV & 3 & 4.76 \\
\hline Total & 63 & 100 \\
\hline
\end{tabular}

Table 2 shows grade wise distribution of cases. In present study, 8 eyes had grade I pterygium, 27 eyes had grade II pterygium, 25 eyes had grade III pterygium and 3 eyes had grade IV.

Table No. 3: Comparison of grade wise pre-op and post op astigmatism

\begin{tabular}{|c|c|c|c|}
\hline Grades Of Pterygium & $\begin{array}{l}\text { Pre-Op Mean Astigmatism } \\
\text { D +/_SD }\end{array}$ & $\begin{array}{l}\text { Post-Op Mean Astigmatism } \\
\text { D +/_SD }\end{array}$ & P Value \\
\hline Grade I & $2.19+/ 0.22$ & $0.97+/[0.28$ & 0.515 \\
\hline Grade II & 2.59+/_0.72 & $1.21+/ 0.43$ & $<0.001$ \\
\hline GradeIII & 3.56+/_0.63 & 1.64+/_0.66 & $<0.001$ \\
\hline Grade IV & 8.75+/_0.43 & 4.17+/_0.29 & $<0.001$ \\
\hline
\end{tabular}

Table 3 The amount of astigmatism increases as grade of pterygium increases grade I (2.19D \pm 0.22$)$, gradeII (2.59 \pm 0.72$)$, gradeIII (3.56 \pm 0.63$)$, grade IV $(8.75 \pm 0.43)$. Surgical removal of pterygium caused a significant reduction in refractive astigmatism shows that mean astigmatism following pterygium excision surgery is $0.97 \mathrm{D} \pm 0.28$ in grade $\mathrm{I}, 1.21 \mathrm{D} \pm 0.43$ in grade II , $1.64 \mathrm{D} \pm 0.66$ in grade III, $4.17 \pm 0.29$ in grade IV.

Table No. 4: Comparison of mean pre-op and post-op astigmatism 


\begin{tabular}{|l|l|}
\hline Mean Astigmatism & Astigmatism +/_SD \\
\hline Pre -Operative mean & $3.29 \mathrm{D}+$ I_ $_{1} .46$ \\
\hline Post-operative mean & $1.49 \mathrm{D}+$ __$_{0} 0.82$ \\
\hline p-value & $<0.001$ \\
\hline
\end{tabular}

Table 4 shows that mean astigmatism following pterygium surgery reduced from 3.29D \pm 1 .46to $1.49 \mathrm{D} \pm 0.82(\mathrm{p}$ value $<0.001$ )

Table No. 5: Comparison of pre-op and post op BCVA

\begin{tabular}{|l|l|l|l|}
\hline Grades of Pterygium & Pre-Op Mean BCVA & Post-Op Mean BCVA & P value \\
\hline Grade I & $0.85+/ \_0.17$ & $0.95+/ \_0.10$ & 0.184 \\
\hline Grade II & $0.58+/ 0.22$ & $0.79+/ \_0.21$ & $<0.001$ \\
\hline GradeIII & $0.41+/ 0.14$ & $0.56+/ \_0.14$ & $<0.001$ \\
\hline Grade IV & $0.08+/ 0.02$ & $0.18+/ \_0.07$ & $<0.001$ \\
\hline
\end{tabular}

Table 5 shows improvement of best corrected visual acuity in all grades of pterygium following pterygium excision. The improvement was significant in grade II, III, and IV p value $(<0.001)$ and not significant in grade I p value $(0.184)$.

Table No. 6: Mean BCVA following pterygium excision

\begin{tabular}{|l|l|l|}
\hline Pre-Op mean BCVA +/_SD & Post-Op mean BCVA+/_SD & P-value \\
\hline $0.53+/$ _ 0.24 & $0.69+/ \_0.25$ & 0.001 \\
\hline
\end{tabular}

Table 6 shows that improvement in mean BCVA from $0.53 \pm 0.24$ to $0.69 \pm 0.25 \mathrm{p}$ value $(0.001)$, which is statistically significant after pterygium excision surgery.

\section{Discussion}

Pterygium induced refractive change often leads to visual impairment. Previous studies have shown that pterygium causes corneal distortion which induces a significant amount of astigmatism $[5,6,7,8]$. The exact mechanism of flattening in horizontal meridian due to pterygium is not clear. It is thought to be caused by the formation of tear meniscus between the corneal apex $[9,10]$ and the elevated pterygium, causing an apparent flattening of the normal corneal curvature [11]. As this flattening is along the horizontal meridian, it usually causes with the rule corneal astigmatism. Pterygium excision induces a reversal of pterygium related corneal flattening [12]. Consequently successful pterygium surgery should reduce corneal astigmatism [13].

Maheshwari [14] demonstrated that after removal of the pterygium, cornea becomes more regular. Comparison of pre and postoperative corneal topography also revealed significant changes in the majority of topographic parameters. Numerous studies have documented improvement in the corneal condition and topographic indices after pterygium excision [15]. Pterygium can cause an asymmetric distortion of the cornea, because the lesion typically extends radially from the corneal periphery. The disruption to the corneal surface topography induces both coma and trefoil wavefront errors (WFEs) [16,17]. There is commonly an increase in corneal and refractive astigmatism with pterygium as well as an increase in Higher-order wavefront error (HO-WFE), with an effect proportional to the extent of the lesion $[18,19]$. Because the condition approaches lateral to the visual axis, a change in Surface Asymmetry Index (SAI) is not usually a feature of the condition. Higher-order wavefront error is associated with corresponding reduction in visual acuity and contrast sensitivity [20].

Studies indicate that contrast sensitivity testing may provide additional objective methods for documenting impaired vision in patients with pterygium when Snellen visual acuity is minimally affected [21] . Corneal astigmatism and contrast sensitivity values in patients with pterygia are useful indicators for the need of pterygium surgery or as indicators of surgical success [22].

In the present study, 8 eyes had grade 1 pterygium, 27 eyes had grade 2 pterygium, 25 eyes had grade 3 pterygium and 3 eyes had grade 4 pterygium. Our finding are in accordance with the findings of other workers [13,14].The preoperative mean astigmatism was $3.29 \mathrm{D} \pm 1.46$. The amount of astigmatism varied 
with grade of pterygium. The preoperative mean astigmatism was $2.19 \mathrm{D} \pm 0.22 \mathrm{D}$ in grade I pterygium, $2.59 \mathrm{D} \pm 0.72 \mathrm{D}$ was noticed in grade $2,3.56 \mathrm{D} \pm 0.63 \mathrm{D}$ in grade III pterygium and $8.75 \pm 0.43 \mathrm{D}$ in grade IV. Our findings are in accordance with the findings of other workers.

Lin and Stern [24] found a significant correlation between the pterygium size and corneal astigmatism; they reported pterygium to induce significant degrees of astigmatism once it exceeded $>45 \%$ of the radius. With increase in grade of pterygium, induced astigmatism is increased .The maximum degree of astigmatism was noted in grade IV and minimum was in grade I . There was statistically significant correlation between grade of pterygium and induced astigmatism (pvalue<0.001). This calculation was done by ANOVA test.

The astigmatism decreased significantly following pterygium excision. The mean preoperative refractive cylinder decreased from $3.29 \mathrm{D} \pm 1.46 \mathrm{D}$ to $1.49 \pm 0.82 \mathrm{D}$ postoperatively $(p<0.001)$.Astigmatism was with the rule in all patients. Surgical removal of pterygium caused a significant reduction in refractive astigmatism. The mean preoperative refractive cylinder decreased from $2.19 \pm 0.22 \mathrm{D}$ to $0.97 \pm 0.28 \mathrm{D}$ postoperatively $(\mathrm{p}=0.515)$ in grade I pterygium, from $2.59 \pm 0.72 \mathrm{D}$ to $1.21 \pm 0.43 \mathrm{D}$ in grade $2(\mathrm{p}<0.001)$. In grade III pterygium refractive cylinder decreased from $3.56 \pm 0.63$ D to1.64 $\pm 0.66 \mathrm{D}$ postoperatively $(\mathrm{p}<0.001)$. The amount of astigmatism decreased significantly following pterygium excision in grade II and grade III $(p<0.001)$ but in grade I the decrease in amount of astigmatism following pterygium surgery was not statistically significant $(\mathrm{p}=0.515)$. The amount of astigmatism seen in the patients with grade I pterygium (>2D) occurs not only due to pterygium induced refractive changes, but naturally occurring astigmatism was more responsible. This was noticed by the fact that in grade I the amount of astigmatism decrease following pterygium surgery was not statistically significant $(\mathrm{p}=0.515)$.

When primary pterygium increases in size (more than grade 1) it induces significant with the rule astigmatism. This significant astigmatism tend to increase with the increasing size of the lesion. Pterygium induced astigmatism decreased significantly following pterygium excision in grade II, grade III and grade IV.
Surgical intervention resulted in an increase in the mean refractive power one month postoperatively, which indicates steepening of flattened cornea. Pterygium induced astigmatism appears to be due to alteration in tear film caused by lesion. As the head of pterygium approaches the apex of cornea, a tear meniscus develops between the corneal apex and the elevated pterygium, causing an apparent flattening of normal corneal curvature [9].The mean horizontal refractive power of cornea increased from $42.49 \pm 1.00$ to $43.4 \pm 1.26$ ( $\mathrm{p}$ value <0.001) following pterygium excision .There was flattening of cornea horizontally . This flattening dissipated after pterygium removal. Our finding are in accordance with the findings of other workers [10,12].

Pterygium induced impaired visual acuity may be caused by an alteration in tear film or by mechanical effects of the lesion. Therefore, excision of the lesion may lead to reconstruction of the normal surface, and thus, improvement in the visual acuity [23]. Statistically improvement in BCVA in grade II, grade III and grade IV pterygium was due to reduction of astigmatism.

Lin et.al.in 1989 showed that contrast sensitivity was lower at all spatial frequencies in the patients with pterygium. Another study showed that contrast sensitivity at medium to-high spatial frequencies of 6 , 12 , and $18 \mathrm{cpd}$ significantly improved after pterygium excision, while contrast sensitivity at low spatial frequencies of 1.5 and $3 \mathrm{cpd}$ did not change after surgery [22].

In present study it was observed that contrast sensitivity decreases with increase in grade of pterygium. Contrast sensitivity reduced maximally in grade IV and minimally in grade I. There was statistically significant correlation between grade of pterygium and contrast sensitivity. Our finding are in accordance with the findings of Lin et al in 1989. The contrast sensitivity improved significantly following pterygium excision The mean preoperative contrast sensitivity increased from $1.49 \pm 0.21$ to $1.70 \pm 0.20$ postoperatively. Surgical removal of pterygium caused a significant improvement in contrast sensitivity. The mean preoperative contrast sensitivity improved from1.69 \pm 0.20 to $1.83 \pm 0.20$ postoperatively $(\mathrm{p}=0.22)$ in grade I pterygium, from $1.51 \pm 0.13$ to $1.74 \pm 0.14$ was noticed in grade II. In grade III pterygium contrast sensitivity increased from $1.45 \mathrm{D} \pm 0.19$ to $1.64 \pm 0.16$ postoperatively and in grade IV contrast sensitivity increased from $1.25 \pm 0.10$ to $1.45 \pm 0.10$. The amount of contrast sensitivity increased 
significantly following pterygium excision in grade II, grade III and grade IV but in grade I, the increase in the amount of contrast sensitivity after pterygium excision was not statistically significant ( $p$ value 0.22 ).

\section{Conclusions}

Surgical excision of pterygium improves contrast sensitivity, visual acuity and reduce astigmatism. Contrast sensitivity testing may provide additional objective methods for documenting impaired vision in patients with pterygium when Snellen visual acuity is minimally affected Corneal astigmatism and contrast sensitivity values in patients with pterygia are useful indicators for the need of pterygium surgery or as indicators of surgical success.

\section{Funding:Nil. Conflict of interest: Nil. Permission for IRB: Yes}

\section{References}

1. Taylor HR, West S, Muñoz B, Rosenthal FS, Bressler $\mathrm{SB}$, Bressler NM. The long-term effects of visible light on the eye. Arch Ophthalmol. 1992 Jan;110(1):99104.

2. Taylor HR, West SK, Rosenthal FS, Munoz B, Newland HS, Emmett EA. Corneal changes associated with chronic UV irradiation. Arch Ophthalmol. 1989 Oct;107(10):1481-4.

3. Threlfall TJ, English DR. Sun exposure and pterygium of the eye: a doseresponse curve. Am J Ophthalmol. 1999 Sep;128(3):280-7.

4. David B. Elliott, Mark A. Bullimore and Ian L. Bailey. Improving the reliability of the pelli-robson contrast sensitivity test. Clin. Vision Sci. Vol. 6,No. 6,pp. 471-475,1999

5. Tomidokoro A, Miyata K, Sakaguchi Y, Samejima $\mathrm{T}$, Tokunaga T, Oshika T. Effects of pterygium on corneal spherical power and astigmatism. Ophthalmology. 2000 Aug;107(8):1568-71.

6. Gütay A, Küchle M, Kus MM, Langenbucher A Impact of pterygium size on corneal topography and visual acuity - a prospective clinical cross-sectional study. Lindsay RG1, Sullivan LKlin Monbl Augenheilkd. 2001 Sep;218(9):609-1.
7. Bahar, Irit MD; Loya, Nisim MD; Weinberger, Dov MD; Avisar, Rahamim MD.Effect of Pterygium Surgery on Corneal Topography:: A Prospective Study Cornea: 2004 Mar;23(2):113-7

8. Yilmaz S, Yuksel T, Maden A. Corneal topographic changes after four types of pterygium surgery. J Refract Surg. 2008 Feb;24(2):160-5.

9. Oldenburg JB, Garbus J, McDonnell JM, McDonnell PJ. Conjunctival pterygia. Mechanism of corneal topographic changes. CorneaCan J Ophthalmol. 2012 Oct;47(5):423-8. doi: 10.1016/j.jcjo.2012.07.002.

10. Cinal A, Yasar T, Demirok A, Topuz H. The effect of pterygium surgery on corneal topography. Ophthalmic Surg Lasers. 2001 Jan-Feb;32(1):35-40.

11. Hong JW, Lee TS. Comparison of Refractive Change Measured by corneal topography before and after pterygium excision.J Korean opthalmol Soc. 1996 $\operatorname{Oct}(10): 1614-1689$

12. Yagmur M, Ozcan AA, Sari S, Ersöz TR. Visual acuity and corneal topographic changes related with pterygium surgery. J Refract Surg. 2005 MarApr;21(2):166-70.

13. Yousuf M. Role of pterygium excision in pterygium induced astigmatism. JK-Practitioner 2005;12:91-2

14. Maheshwari

S.

Effect of pterygium excision on pterygium induced asti gmatism. Indian J Ophthalmol. 2003 Jun;51(2):187-8.

15. Stern GA, Lin A. Effect of pterygium excision on induced corneal topogr aphic abnormalities. Cornea. 1998 Jan;17(1):23-7.

16. Applegate RA, Hilmantel G, Howland HC, Tu EY, Starck T, Zayac EJ. Corneal first surface optical aberrations and visual performance. J Refract Surg. 2000 Sep-Oct;16(5):507-14.

17. Pesudovs K, Figueiredo FC. Corneal first surface wavefront aberrations before and after pterygium surgery. J Refract Surg. 2006; 22: 921-5

18. Gumus K, Topaktas D, Göktaş A, Karakucuk S, Oner A, Mirza GE. The change in ocular higherorder aberrations after pterygium excision with conjunct 
ival autograft: a 1-yearprospective clinical trial. Cornea. 2012 Dec;31(12):1428-31. doi: 10.1097/ICO.0b013e3182431465.

19. Kwon SM, Lee DJ, Jeung WJ, Park WC. Power vector and aberrations using corneal topographer and wavefront aberrometer before and after pterygium surgery. J Korean Ophthalmol Soc. 2008; 49: 1737-45.

20. Applegate RA, Hilmantel G, Howland HC, Tu EY, Starck T, Zayac EJ. Corneal first surface optical aberrations and visual performance. J Refract Surg. 2000 Sep-Oct;16(5):507-14.

21. Lin S, Reiter K, Dreher AW, Frucht-Pery J, Feldman ST. The effect of pterygia on contrast sensitivity and glare disability. Am J Ophthalmol. 1989 Apr 15;107(4):407-10.
22. Oh JY, Wee WR. The effect of pterygium surgery on contrast sensitivity and corneal topographic changes. Clin Ophthalmol. 2010 Apr 26;4:315-9.

23.Razmjoo H, Vaezi MH, Peyman A, Koosha N, Mohammadi Z, Alavirad M. The effect of pterygium surgery on wave front analysis. Adv Biomed Res. 2014 Sep 23;3:196. doi: 10.4103/22779175.140677. eCollection 2014.

24. Pujol P, Julio G, de Carvalho AM, Kostov B, MartíHuguet T. Threshold to predict astigmatism reduction after pterygium excision. Optom Vis Sci. 2014 Jul;91(7):747-51. doi: 10.1097/OPX.0000000000000307.

\section{How to cite this article?}

Kujur R, Vohra M, Adlakha N, Shakya D.K, Shukla A. To study the effect of pterygium excision on corneal curvature and contrast sensitivity. Int J Med Res Rev 2015;3(11):1281-1287. doi: 10.17511/ijmrr.2015.i11.233. 